\title{
Kebijakan Komunikasi di Indonesia: Gambaran Implementasi UU No. 14 tahun 2008 tentang Keterbukaan Informasi Publik
}

\author{
Agusly Irawan Aritonang \\ Alumnus Program Studi Ilmu Komunikasi UAJY dan telah menyelesaikan \\ Program Pascasarjana Ilmu Komunikasi, UGM
}

\begin{abstract}
Freedom of getting information is also one of democracy state's features since it is expected to stimulate participation of citizen. Furthermore, if there is more public information which can be got freely, it will strengthen the tendency of the change of society type into informative society. Indonesia tried to facilitate its citizens by provided such a basic bill in order to access the public information. As a communication policy, this regulation has been implemented since its validity 2 years ago. This implementation of policy such as Bill No. 14 of 2008 talks about The Transparency of Public Information become such a complicated problem. Problem related to regulation's article which has to be as operational as possible when it will be implemented and also about its accuracy are factors that become a success key for public policy implementation involved the communication policy.
\end{abstract}

Keyword: Transparency of Public Information, Regulation Implementation, Communications Regulation

\section{Pendahuluan}

Pemerintah Republik Indonesia bersama DPR menyepakati terbitnya UU No 14 tahun 2008 tentang Keterbukaan Informasi Publik (KIP), secara resmi UU ini disahkan pada tanggal 30 April 2008 dan resmi berlaku pada tanggal 1 Mei 2010. Jeda waktu ini dimaksudkan agar UU ini bisa tersosialisasikan dengan baik sehingga UU ini harapannya dapat berjalan dengan maksimal bagi masyarakat sebagai penggunanya.

UU No. 14 tahun 2008 tentang KIP ini awalnya merupakan inisiatif DPR bersama civil society yang diwakili berbagai LSM. Alasannya sederhana yaitu sebuah informasi merupakan sebuah hak asasi yang dimiliki setiap manusia. Selain itu harapan keterbukaan informasi yang bisa difasilitasi melalui sebuah dasar hukum yang kuat juga akan mendorong transparansi dalam pengelolaan negara yang pada akhirnya juga akan meningkatkan partisipasi masyarakat. Singkatnya, UU ini memiliki cita-cita yang mulia. Namun prakteknya hingga saat ini pelaksanaan UU ini masih sangat lambat, bisa dilihat dari indikatorindikator sederhana yang mudah dilihat dan diukur mulai dari kesiapan organ- 
organ pendukung seperti KI (Komisi Informasi) baik Pusat hingga Provinsi yang harus ada di setiap provinsi hingga tataran yang paling sulit untuk dinilai dan diukur seperti budaya transparansi di tiap badan publik.

Harus diakui UU no. 14 tahun 2008 tentang KIP ini berimplikasi luas dan serius. Jika benar-benar diterapkan, badan publik tidak bisa lagi menyepelekan sebuah informasi karena sewaktu-waktu bisa saja pemohon informasi publik mengajukan permohonan informasi publik ke badan publik tersebut. Bahkan terhadap sebuah informasi yang bersifat rahasia bisa saja dibuka jika informasi tersebut sudah diputuskan oleh Komisi Informasi untuk dibuka. Artinya, badan publik harus benar-benar mempersiapkan dirinya secara jeli agar bisa menjalankan amanat UU ini secara optimal.

Ada banyak faktor yang membuat UU ini lambat untuk diimplementasikan. Tidak seperti Kebijakan Komunikasi lainnya seperti UU No. 32 tahun 2002 tentang Penyiaran yang "hanya" mengatur lembaga penyiaran atau UU Informasi dan Transaksi Elektronik, UU ini menyasar badan publik (dengan defenisinya yang luas) yang harus menyediakan setiap informasi kepada masyarakat. Tentu badan publik harus hati-hati dalam menyikapi persoalan ini. Beberapa faktor yang bisa dikedepankan dalam tulisan ini adalah faktor UU No. 14 tahun 2008 itu sendiri maupun faktor implementasinya di lapangan. Kedua faktor ini cukup penting karena selain implementasi di lapangan yang menemui banyak persoalan namun faktor UU nya sendiri juga memiliki beberapa kendala. Tulisan ini mencoba untuk memberikan sedikit gambaran mengenai rumitnya implementasi UU N0. 14 tahun 2008 tentang Keterbukaan Informasi Publik.

Namun sebelum membahas tentang UU ini secara lebih lanjut diperlukan sebuah perspektif untuk memberikan alur pemikiran dalam memahami sebuah kebijakan khususnya kebijakan komunikasi.

\section{Kebijakan Komunikasi : Sebuah \\ Perspektif}

Salah satu perpektif yang dikenal dalam ilmu komunikasi yaitu perspektif kebijakan. Istilah perspektif digunakan oleh Ashadi Siregar (1998) untuk merujuk pada teori yang digunakan untuk keperluan analisis dalam suatu disiplin keilmuan dengan objek formal yang berbeda. Pendapat ini berangkat dari kenyataan bahwa komunikasi bukanlah sebuah ilmu murni melainkan sebuah kajian yang perlu meminjam teori-teori dari bidang keilmuan lainnya.

Kebijakan komunikasi sendiri memiliki pengertian yang beragam. Salah satu pendapat mengenai kebijakan komunikasi yaitu pengertian menurut Unesco yang dikutip Ugboajah (1980:5) yang menyampaikan bahwa kebijakan komunikasi sebagai kumpulan prinsipprinsip dan norma-norma yang sengaja diciptakan untuk mengatur perilaku sistem komunikasi. Pengertian sederhana ini mengandung pemahaman bahwa sebuah kebijakan komunikasi lahir setelah adanya sebuah sistem komunikasi yang berlaku di sebuah negara. Setiap negara diyakini memiliki sebuah pola-pola komunikasi yang berjalan dan berproses membentuk sebuah sistem. Sistem yang terdiri dari sub-subsistem menjalankan 
fungsi masing-masing dan memerlukan sebuah regulasi agar subsistem tersebut dapat berjalan tanpa saling berbenturan satu sama lain. Singkatnya, Kebijakan Komunkasi dilahirkan untuk memperlancar sistem komunikasi.

Kebijakan komunikasi setidaknya memiliki 3 bagian penting. Bagian ini dikenal dengan konteks, domain, dan paradigma. Konteks berarti keterkaitan kebijakan komunikasi dengan sesuatu yang melingkupi dirinya seperti politikekonomi, politik komunikasi,dll. Domain kebijakan komunikasi berarti muatan nilai yang dikandung dalam sebuah kebijakan komunikasi seperti globalisasi, ekonomi global,dll. Sedangkan paradigma lebih kepada kerangka citacita yang menjadikan tujuan kebijakan komunikasi tersebut. (Abrar, 2008: 4). Dalam konteks paradigma, kebijakan Informasi dan Transaksi Elektronik maupun Keterbukaan Informasi Publik yang dikeluarkan pemerintah memiliki cita-cita ke arah masyarakat informasi.

Kebijakan komunikasi setidaknya memiliki 5 kriteria. Menurut Abrar, kriteria ini berkaitan dengan bentuk kebijakan komunikasi sebagai sebuah kebijakan publik. Kriteria tersebut yaitu:

1. Memiliki tujuan tertentu

Sebuah regulasi, atau kebijakan apa pun tentu memiliki sebuah tujuan. Seperti yang sudah disebutkan sebelumnya setiap kebijakan komunikasi dilahirkan untuk memperlancar jalannya sistem komunikasi. Secara spesifik, setiap kebijakan komunikasi memiliki tujuan yang bisa dilihat dari pasal-pasal awal.

2. Berisi tindakan pejabat pemerintah.
Kebijakan komunikasi dilahirkan oleh perangkat pemerintahan. Kebijakan komunikasi setingkat UU misalnya, dilahirkan oleh DPR setelah berkonsultasi dengan pemerintah. Secara teknis UU memerlukan perangkat aturan lebih rendah dibawahnya agar dapat berjalan lebih maksimal. Peraturan Pemerintah (PP), Keputusan Presiden (Kepres), Keputusan Mentri (KepMen) merupakan bagian-bagian dari pemerintah. Artinya setiap produk kebijakan merupakan hasil tindakan pemerintah karena dihasilkan oleh perangkat pemerintahan.

3. Memperlihatkan apa yang akan dilakukan pemerintah.

Sebagai akibat kebijakan dihasilkan oleh aparat pemerintah maka kebijakan menunjukkan apa yang akan dijalankan oleh pemerintah. Namun perlu diperhatikan bahwa kebijakan komunikasi bukanlah berisi keinginan pemerintah tentang bagaimana sebuah proses komunikasi berlangsung. Pemerintah dalam konteks ini berperan sebagai fasilitator setelah adanya keinginan dari kelompok masyarakat agar dibuat sebuah regulasi/kebijakan.

4. Bisa bersifat positif atau negatif

Sebuah kebijakan komunikasi sangat dimungkinkan untuk bernilai positif meupun negatif. Sebuah kebijakan komunikasi dinilai baik jika ia mampu menjawab persoalan yang muncul bahkan jika kebijakan tersebut mampu mengantisipasi perubahan yang terjadi ke depan sekaligus mudah untuk diimplementasikan. Namun 
juga tidak menutup kemungkinan jika sebuah kebijakan komunikasi lahir bersifat negatif karena sebuah kebijakan juga berisi tarik menarik sebuah kepentingan. Namun satu yang pasti sebuah kebijakan apapun akan melahirkan pro dan kontra.

5. Bersifat memaksa (otoritatif)

Kebijakan komunikasi sebagai sebuah kebijakan publik dilahirkan oleh perangkat negara. Satu hal yang menjadi ciri negara adalah kekuasaan yang bersifat memaksa yang dimilikinya. Artinya setiap keputusankeputusan yang dihasilkan oleh negara wajib untuk dijalankan. Jika ada pelanggaran terhadap apa yang sudah diputuskan oleh pemerintah maka adan sanksi terutama sanksi hukum yang bersifat mengikat bagi pelanggarnya.

Kebijakan komunikasi setidaknya memiliki 2 tujuan, yaitu :

1. Secara sosiologis menempatkan proses komunikasi sebagai bagian dari dinamika sosial yang tidak merugikan masyarakat. Hal ini didasarkan bahwa setiap masyarakat dimanapun mereka berada memiliki sebuah bentuk atau proses komunikasi. Proses komunikasi ini tentu saja memiliki dinamika yang terus berkembang secara naik maupun turun. Tentu saja dinamika ini perlu dijaga agar bergerak ke arah yang positif. Kebijakan di sini memainkan peranan yang penting. Kebijakan komunikasi harus bisa menjamin dinamika sosial masyarakat berjalan secara positif dan bisa meminimalkan ketimpangan-ketimpangan misalnya adanya dominasi dari satu pihak atas pihak lain. Maka penyusunan sebuah kebijakan diperlukan keterlibatan pihak masyarakat.

2. Komunikasi merupakan sesuatu keniscayaan dalam masyarakat. Komunikasi dipandang sebagai sebuah sistem dimana sebuah sistem yang terdiri dari subsistem-subsistem. Ada kalanya subsistem-subsistem berjalan dengan tidak maksimal. Ada masalah, ada hambatan. Maka Kebijakan Komunikasi lahir untuk memperlancar proses berjalannya sistem komunikasi.(Abrar, 2008: 1617)

Sebuah kebijakan komunikasi tak bisa dilepaskan dari kebijakan publik. Hal ini disebabkan karena kebijakan komunikasi juga merupakan salah satu bagian dari kebijakan publik. Kebijakan publik secara sederhana dapat dipahami sebagai apa yang dipilih oleh pemerintah untuk dikerjakan maupun tidak dikerjakan. (Thomas.1995: 1)

Pendapat ini disampaikannya dimana konsep ini sangat luas karena kebijakan publik mencakup sesuatu yang tidak dilakukan oleh pemerintah di samping yang dilakukan oleh pemerintah ketika pemerintah menghadapi masalah publik. Defenisi sederhana ini mengandung makna bahwa kebijakan publik dibuat oleh badan pemerintah, bukan organisasi swasta dan kebijakan publik menyangkut pilihan yang harus dilakukan atau tidak dilakukan oleh badan pemerintah. (Subarsono, 2005: 2) Selain itu ada beberapa defenisi kebijakan publik yang disampaikan beberapa ahli lainnya seperti :

1. Richard Rose (1969: 79) menyebut 
kebijakan publik sebagai serangkaian kegiatan yang sedikit banyak berhubungan beserta konsekuensi-konsekuensinya bagi mereka yang bersangkutan daripada sebagai suatu keputusan tersendiri. Meskipun defenisi ini dinilai ambigu namun defenisi ini juga mampu memberi arah atau pola kegiatan dan bukan sekedar suatu keputusan untuk melakukan sesuatu. (dalam Winarno, 2007: 17).

2. Carl Friedrich (1969:79) menyatakan kebijakan adalah serangkaian tindakan/kegiatan yang diusulkan oleh seseorang, kelompok, atau pemerintah dalam suatu lingkungan tertentu dimana terdapat hambatanhambatan (kesulitan-kesulitan) dan kemungkinan-kemungkinan (kesempatan-kesempatan) dimana kebijakan tersebut diusulkan agar berguna dalam mengatasi untuk mencapai tujuan yang dimaksud.

3. James Anderson (1984:3) memberi pengertian tentang kebijakan publik sebagai serangkaian kegiatan yang mempunyai maksud/ tujuan tertentu yang diikuti dan dilaksanakan oleh seorang aktor atau sekelompok aktor yang berhubungan dengan suatu permasalahan atau suatu hal yang diperhatikan. Konsep kebijakan ini menitikberatkan pada apa yang sesungguhnya dikerjakan daripada apa yang diusulkan atau dimaksud.

4. Leslie A. Pal (1987:4) mengemukakan bahwa kebijakan diartikan "as a course of action or inaction choosen by public authorities to address a given problem or interelated set of problems." (dalam Widodo, 2007: 12).
Kebijakan publik sebagai bagian dari suatu kegiatan memiliki sifat yaitu:

1. Policy demands atau permintaan kebijakan yaitu permintaan/kebutuhan/klaim yang dibuat oleh warga masyarakat secara pribadi/kelompok dengan resmi dalam sistem politik oleh karena adanya masalah yang mereka rasakan. Permintaan tersebut dapat berupa desakan secara umum kepada pemerintah dimana pemerintah harus melakukan sesuatu ataupun berupa usulan untuk bertindak dalam masalah tertentu. Keinginan publik akan penyelesaian suatu masalah yang mendorong lahirnya sebuah kebijakan publik yang dibuat untuk memuaskan warga.

2. Policy decisions atau putusan kebijakan yaitu putusan yang dibuat oleh pejabat publik yang memerintahkan untuk memberi arahan padakegiatan-kegiatan kebijakan misalnya mengeluarkan ketetapan, mengeluarkan atau mengumumkan perintah eksekutif, mengumumkan aturan administratif, atau membuat interpretasi hukum yang penting.

3. Policy statements atau pernyataan kebijakan yaitu ungkapan secara formal atau artikulasi dari keputusan politik yang telah ditetapkan misalnya ketetapan legislatif, dekrit dan perintah eksekutif, peraturan administratif, pendapat pengadilan, pidato-pidato yang dilakukan oleh pejabat publik yang menandakan maksud dan tujuan dari pemerintah serta apa yang akan dikerjakan untuk mewujudkannya

4. Policy output atau hasil kebijakan 
adalah "perwujudan nyata" dari kebijakan publik; yaitu sesuatu yang dikerjakan menurut keputusan dan pernyataan kebijakan. Output juga bisa dikatakan sebagai apa yang dikerjakan pemerintahnamun berbeda dengan apa yang akan dikerjakan oleh pemerintah. Kebijakan biasanya dititikberatkan pada masalahmasalah seperti pengumpulan pajak, blokade pada pedagang kaki lima, pembangunan jalan raya, dll

5. Policy outcomes atau akibat dari kebijakan adalah konsekuensi kebijakan yang diterima masyarakat, baik yang diinginkan atau tidak diinginkan yang berasal dari apa yang dikerjakan atau yang tidak dikerjakan oleh pemerintah.(Agustino, 2008: 10)

Kebijakan publik sendiri merupakan sebuah hasil dari prosesyang panjang. Ada banyak pendapat yang menyampaikan tentang proses sebuah kebijakan publik. Dunn (1999: 24-29) menyampaikan salah satunya dimana sebuah proses kebijakan publik melewati beberapa tahap yaitu:

1. Tahap penyusunan agenda yaitu tahap dimana pejabat yang dipilih dan diangkat menempatkan masalah pada agenda publik. Banyak masalah tidak disentuh sama sekali, sementara lainnya ditunda untuk waktu lama. Jika dilihat dari analisis kebijakan, tahap ini disebut dengan tahap rumusan masalah. Perumusan masalah dapat memasok pengetahuan yang relevan dengan kebijakan yang mempersoalkan asumsi-asumsi yang mendasari defenisi masalah dan memasuki proses pembuatan kebijakan melalui penyusunan agenda.
Perumusan masalah dapat membantu menemukan asumsi-asumsi yang tersembunyi, mendiagnosis penyebab-penyebabnya, memetakan tujuan-tujuan yang memungkinkan, memadukan pandangan-pandangan yang bertentangan, dan merancang peluang-peluang kebijakan yang baru.

2. Tahap formulasi kebijakan yaitu tahap dimana para pejabat merumuskan alternatif kebijakan untuk mengatasi masalah. Alternatif kebijakan melihat perlunya membuat perintah eksekutif, keputusan peradilan, dan tindakan legislatif. Dari sisi analisis kebijakan, tahap ini disebut tahap peramalan. Peramalan dapat menyediakan pengetahuan yang relevan dengan kebijakan tentang masalah yang akan terjadi di masa mendatang sebagai akibat dari diambilnya alternatif, termasuk tidak melakukan sesuatu. Peramalan dapat menguji masa depan yang plausibel, potensial, dan secara normatif bernilai, mengestimasi akibat dari kebijakan yang ada atau yang diusulkan, mengenali kendalakendala yang mungkin akan terjadi dalam pencapaian tujuan, dan mengestimasi kelayakan politik dari berbagai pilihan.

3. Tahap adopsi kebijakan yaitu tahap dimana alternatif kebijakan yang diadopsi dengan dukungan mayoritas legislatif, konsensus diantara direktur lembaga, atau keputusan peradilan. Sisi analisis kebijakan tahap adopsi dikenal dengan rekomendasi. Rekomendasi akan menghasilkan pengetahuan yang relevan dengan kebijakan tentang manfaat atau biaya dari berbagai alternatif yang akibatnya 
dimasamendatangtelahdiestimasikan melalui peramalan. Rekomendasi membantu mengestimasi tingkat resiko dan ketidakpastian, mengenali eksternalitas dan akibat ganda, menentukan kriteria dalam pembuatan pilihan, dan menentukan pertanggungjawaban administratif bagi implementasi kebijakan.

4. Tahap implementasi kebijakan yaitu tahap dimana kebijakan yang telah diambil dilaksanakan oleh unit-unit administrasi yang memobilisasikan sumber daya finansial dan manusia. Tahap analisis kebijakan pada tahap implementasi disebut dengan pemantauan (monitoring). Pemantauan menyediakan pengetahuan yang relevan dengan kebijakan tentang akibat dari kebijakan yang diambil sebelumnya. Pemantauan akan membantu menilai tingkat kepatuhan, menemukan akibat-akibat yang tidak diinginkan dari kebijakandan program, mengidentifikasi hambatan dan rintangan implementasi, dan menemukan letak pihak-pihak yang bertanggung jawab pada setiap kebijakan.

5. Tahap penilaian yaitu tahap dimana unit-unit pemeriksaan dan akuntansi dalam pemerintahan menentukan apakah badan-badan eksekutif, legislatif, dan peradilan memenuhi persyaratan undang-undang dalam pembuatan kebijakan dan pencapaian tujuan. Evaluasi membuahkan pengetahuan yang relevan dengan kebijakan tentang ketidak sesuaian antara kinerja kebijakan yang diharapkan dengan yang benar-benar dihasilkan. Evaluasi akan menghasilkan kesimpulan mengenai seberapa jauh masalah yang telah terselesaikan dan menyumbang klarifikasi serta kritik terhadap nilai-nilai yang mendasari kebijakan disamping membantu dalam penyesuaian dan perumusan kembali masalah

Berbicara tentang pelaksanaan di lapangan sebuah kebijakan berarti membicarakan tahapan keempat yaitu tahap implementasi kebijakan. Implementasi kebijakan publik memiliki banyak pengertian. Van Meter dan Van Horn (1975) menyebutkan implementasi sebagai tindakan-tindakan yang dilakukan baik oleh individu-individu atau pejabat-pejabat atau kelompokkelompok pemerintah atau swasta yang diarahkan pada tercapainya tujuantujuan yang telah digariskan dalam keputusan kebijakasanaan. Artinya secara sederhana implementasi dapat dipahami sebagai cara agar sebuah kebijakan dapat mencapai tujuannya. Berdasarkan pengertian yang disebutkan Van Meter dan Van Horn, implementasi kebijakan menyangkut 3 hal yaitu: adanya tujuan atau sasaran kebijakan, adanya aktivitas atau kegiatan pencapaian tujuan, dan adanya hasil kegiatan.(Meter \&Horn, dikutip Agustino, 2008:139).

Menurut Riant (2008 : 433) ada 2 cara agar sebuah kebijakan dapat diimplementasikan yaitu langsung mengimplementasikan dalam bentuk program atau membuat formulasi kebijakan derivat atau turunan dari kebijakan publik tersebut. Sebagai sebuah UU memerlukan peraturan pelaksana yang lebih operasional sehingga amanat UU tersebut bisa dijalankan.

Implementasi sebuah kebijakan dapat 
dijelaskan dengan beberapa pendekatan. Pendekatan ini juga bermacam-macam. Leon dan Leon (2001) menyebutkan ada 3 pendekatan di implementasi kebijakan. Pendekatan ini dikenal dengan istilah generasi. Generasi I muncul pada sekitar 1970-an dimana pendekatan ini memahami implementasi kebijakan sebagai masalahmasalah yang terjadi antara kebijakan dan eksekusinya. Tokoh generasi ini antara lain Graham T. Allison. Generasi II muncul sekitar tahun 1980-an yaitu generasi yang mengembangkan pendekatan implementasi kebijakan yang bersifat dari atas ke bawah (top-downer perspective). Perspektif ini cocok dengan birokrasi yang menjalankan kebijakan yang diputuskan lebih bersifat politis. Peneliti yang identik dengan pendekatan semacam ini antara lain Daniel Mazmanian dan Paul Sabatier (1983), Robert Nakamura dan Frank Smallwood (1980), dan Paul Berman (1980). Saat yang hampir bersamaan dengan model top downer, muncul kebalikan dari top downer yaitu bottom upper. Pendekatan ini dikenalkan oleh Michael Lipsky (1971,1980), Benny Hiern (1982,1983). Terakhir, generasi ketiga sekitar 1990an yang kemukakan oleh Malcolm L. Goggin (1990) memperkenalkan pendekatan ketiga yaitu implementasi yang memperhitungkan variabel perilaku aktor pelaksana implementasi kebijakan yang dianggap lebih menentukan keberhasilan implementasi kebijakan. Saat yang sama juga muncul pendekatan situasional dalam implementasi dimana implementasi kebijakan banyak didukung oleh adaptabilitas implementasi kebijakan tersebut. Tokoh-tokoh yang terkenal dengan pendekatan ini antara lain Richard Matland (1995),Helen Ingram (1990), dan
Denise Scheberle (1997). (dalam, Riant, 2008: 437-438).

Van Meter dan Van Horn, (dalam Leo, 2008:144), mengandaikan bahwa implementasi kebijakan berjalan secara linier dari keputusan politik yang tersedia, pelaksana, dan kinerja kebijakan publik. Van Metter dan Van Horn menyampaikan ada 6 variabel yang mempengaruhi kinerja kebijakan publik yaitu:

1. Ukuran dan Tujuan Kebijakan

Kinerja implementasi kebijakan dapat diukur tingkat keberhasilannya jika ukuran dan tujuan dari kebijakan memang realistis dengan sosio kultur yang ada di level pelaksana kebijakan. Ketika ukuran kebijakan atau tujuan kebijakan terlalu ideal (bahkan terlalu utopis) untuk dilaksanakan di level warga maka agak sulit memang merealisasikan kebijakan publik hingga titik yang dapat dikatakan berhasil.

\section{Sumberdaya}

Keberhasilan proses implementasi kebijakan sangat tergantung dari kemampuan memanfaatkan sumberdaya yang tersedia. Manusia merupakan sumberdaya yang terpenting dalam menentukan suatu keberhasilan proses implementasi. Tahap-tahap tertentu dari keseluruhan proses implementasi menuntut adanya sumberdaya manusia yang berkualitas sesuai dengan pekerjaan yang diisyaratkan oleh kebijakan yang telah ditetapkan secara apolitik. Tetapi ketika kompetensi dan kapabilitas dari sumber-sumberdaya itu nihil maka kinerja kebijakan publik sangat 
sulit untuk diharapkan. Sumberdaya lain adalah sumberdaya finansial dan sumberdaya waktu. Kedua sumberdaya ini juga penting karena keterbatasan sumberdaya finansial atau waktu yang terbatas meski tersedia orang-orang yang kompeten untuk melaksanakan sebuah kebijakan bisa membuat sebuah kebijakan berjalan dengang tidak optimal. Maka Van Metter dan Van Horn menekankan kombinasi ketiga sumberdaya ini.

3. Karakteristik Agen Pelaksana

Agen pelaksana dalam konteks ini adalah organisasi formal dan organisasi informal yang akan terlibat pengimplementasian kebijakan publik. Hal ini juga penting karena kinerja implementasi kebijakan sangat dipengaruhi oleh ciri-ciri yang tepat serta cocok dengan para agen pelaksananya. Cakupan atau luas wilayah implementasi kebijakan perlu diperhitungkan manakala hendak menentukan agen pelaksana. Semakin luas cakupan implementasi kebijakan maka seharusnya semakin besar pula agen yang dilibatkan.

4. Sikap/Kecendrungan para pelaksana Sikap penerimaan atau penolakan dari agen pelaksana akan sangat banyak mempengaruhi keberhasilan atau tidaknya kinerja implementasi kebijakan publik. Pendapat ini didasarkan pandangan bahwa kebijakan lahir dan dilaksanakan tidak selalu dari masyarakat yang tahu persoalan yang akan diselesaikan oleh kebijakan tersebut sehingga penolakan sangat mungkin akan terjadi. Lagi pula sifat kebijakan yang top down memungkinkan para pengambil keputusan berasal dari kalangan yang tidak menyentuh kebutuhan, keinginan, atau persoalan yang warga ingin selesaikan.

5. Komunikasi antarorganisasi dan Aktivitas Pelaksana

Koordinasi merupakan mekanisme yang ampuh dalam implementasi kebijakan publik. Semakin baik koordinasi komunikasi diantara pihakpihak yang terlibat dalam suatu proses implementasi maka asumsinya kesalahan-kesalahan akan sangat kecil untuk terjadi. Begitu juga sebaliknya.

6. Lingkungan Ekonomi, Sosial, dan Politik

Lingkungan eksternal pasti berpengaruh dalam implementasi kebijakan. Lingkungan sosial ekonomi dan politik yang tidak kondusif dapat menjadi biang keladi dari kegagalan kinerja implementasi kebijakan karena upaya untuk mengimplementasikan kebijakan harus pula memperhatikan kekondusifan kondisi lingkungan eksternal.

Relasi variabel-variabel dari faktor pengaruh keberhasilan kebijakan versi Van Metter dan Van Horn digambarkan dalam model dibawah ini: 


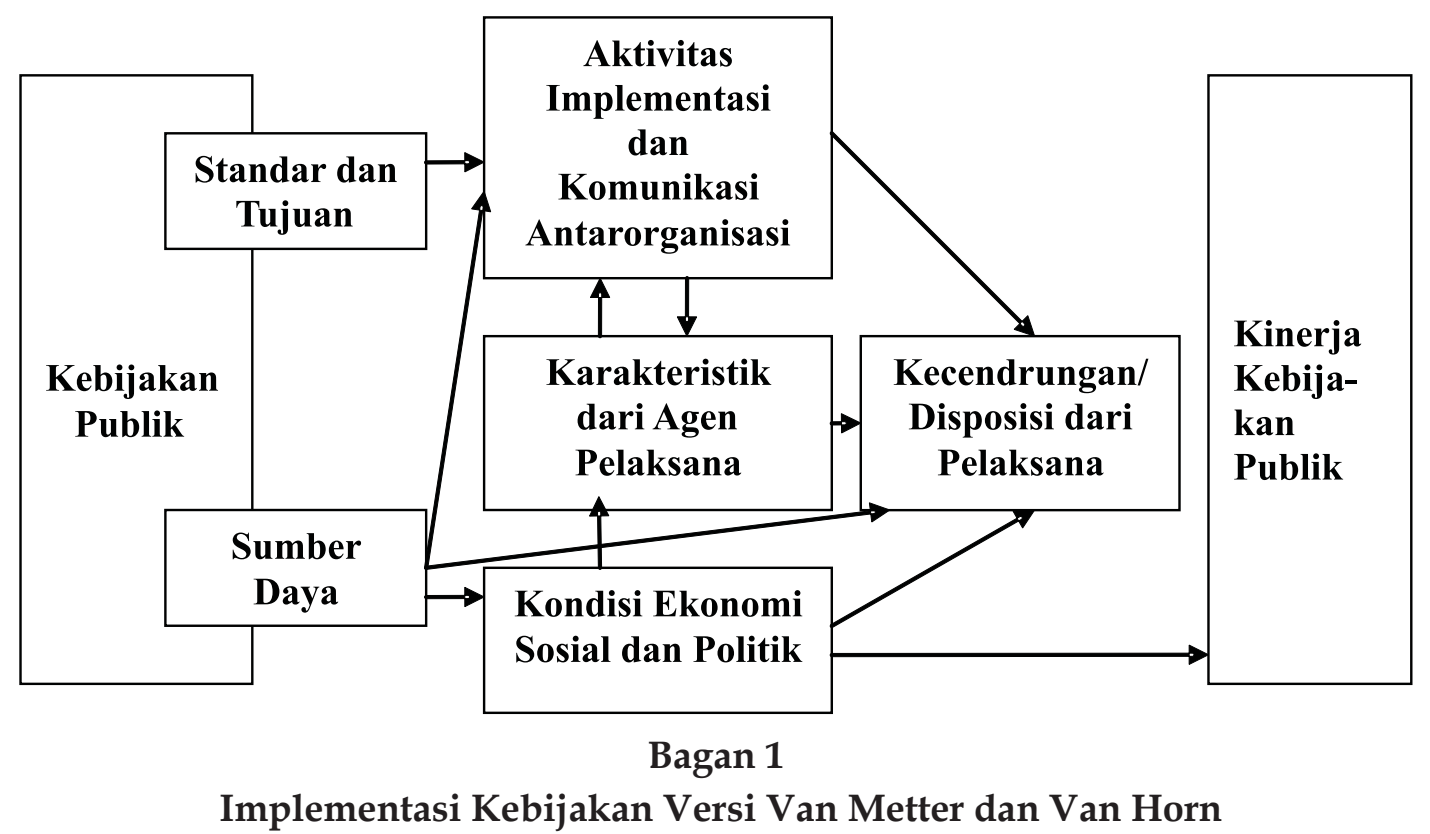

Sumber : (Metter \& Horn, dalam Leo, 2008:144),

UU No.14 tahun 2008 tentang KIP sebagai Kebijakan Komunikasi

Bagian sebelumnya sudah memberikangambaransingkattentang pemikiran tentang kebijakan komunikasi. Gambaran awal tersebut menjelaskan bahwa kebijakan komunikasi bila dipandang sebagai sebuah disiplin ilmu adalah salah satu perspektif komunikasi dimana diperlukan teori untuk keperluan analisis dalam suatu disiplin keilmuan dengan objek formal yang berbeda. Selain itu bab sebelumnya juga memberikan pengertian tentang kebijakan komunikasi, 3 bagianbagian kebijakan komunikasi, tujuan kebijakan komunikasi, dan 5 kriteria kebijakan komunikasi.

UU No.14 tahun 2008 tentang KIP merupakan sebuah kebijakan komunikasi. Ada beberapa alasan yang menjadikan UU ini sebagai sebuah kebijakan komunikasi. Alasan -alasan tersebut yaitu : pertama, sebuah kebijakan komunikasi dibuat bertujuan untuk melancarkan sistem komunikasi.
Dalam konteks Indonesia rumusan Sistem Komunikasi (selanjutnya disebut SKI atau Sistem Komunikasi Indonesia) dibuat berdasarkan focus of interest ilmu komunikasi yang mendasarkan pada informasi dan media. UU No.14 tahun 2008 tentang KIP memfokuskan obyeknya pada persoalan informasi khususnya informasi publik.

Kedua, kebijakan komunikasi dibuat untuk melancarkan Sistem Komunikasi. Lalu Sistem Komunikasi apa yang akan dilancarkan dengan dikeluarkannya UU No.14 tahun 2008 tentang KIP ini? Komunikasi organisasi merupakan salah satu dimensi dari komunikasi. Badan publik merupakan sebuah organisasi yang juga melakukan sebuah proses komunikasi baik secara internal maupun eksternal. Aktivitas sebuah organisasi perlu disampaikan atau dikomunikasikan kepada khalayak luas menjadi sebuah informasi yang tentu penting. Informasi ini terkadang menjadi sebuah obyek yang strategis karena dari informasi ini menjadi 
sumber untuk mengetahui kinerja badan publik. Maka, untuk melancarkan proses berkomunikasi sebuah organisasi (dalam hal ini badan publik) diperlukan sebuah kebijakan atau regulasi tentang informasi yaitu perlunya sebuah kebebasan untuk mengetahui informasi dari badan publik tersebut.

Selain itu informasi dapat diasosiasikan sebagai sebuah pesan dalam proses komunikasi. Jika dalam sebuah proses komunikasi khususnya dalam proses whos says what to whom in which channel with what effect terdapat sebuah ketidaklancaran maka diperlukan sebuah kebijakan komunikasi. UU No 14 tahun 2008 diharapkan bisa melancarkan sebuah proses penyampaian pesan/what tadi.

Ketiga, sebuah kebijakan komunikasi memiliki 3 bagian penting yaitu konteks, domain, dan paradigma. Konteks berarti keterkaitan kebijakan komunikasi dengan sesuatu yang melingkupi dirinya seperti politik-ekonomi, politik komunikasi,dll. Domain kebijakan komunikasi berarti muatan nilai yang dikandung dalam sebuah kebijakan komunikasi seperti globalisasi, ekonomi global,dll. Sedangkan paradigma lebih kepada kerangka citacita yang menjadikan tujuan kebijakan komunikasi tersebut.(Abrar, 2008:4). Dalam UU No. 14 tahun 2008, hal yang paling mudah diperhatikan yaitu paradigma atau kerangka cita-citanya yaitu pengelolaan informasi publik merupakan salah satu upaya untuk mengembangkan masyarakat informasi. Jika dapat diskemakan secara lebih sederhana kaitan antara kebijakan komunikasi sebagai sebuah kebijakan publik dengan implementasinya serta tujuannya maka hasilnya dapat dilihat sebagai berikut:

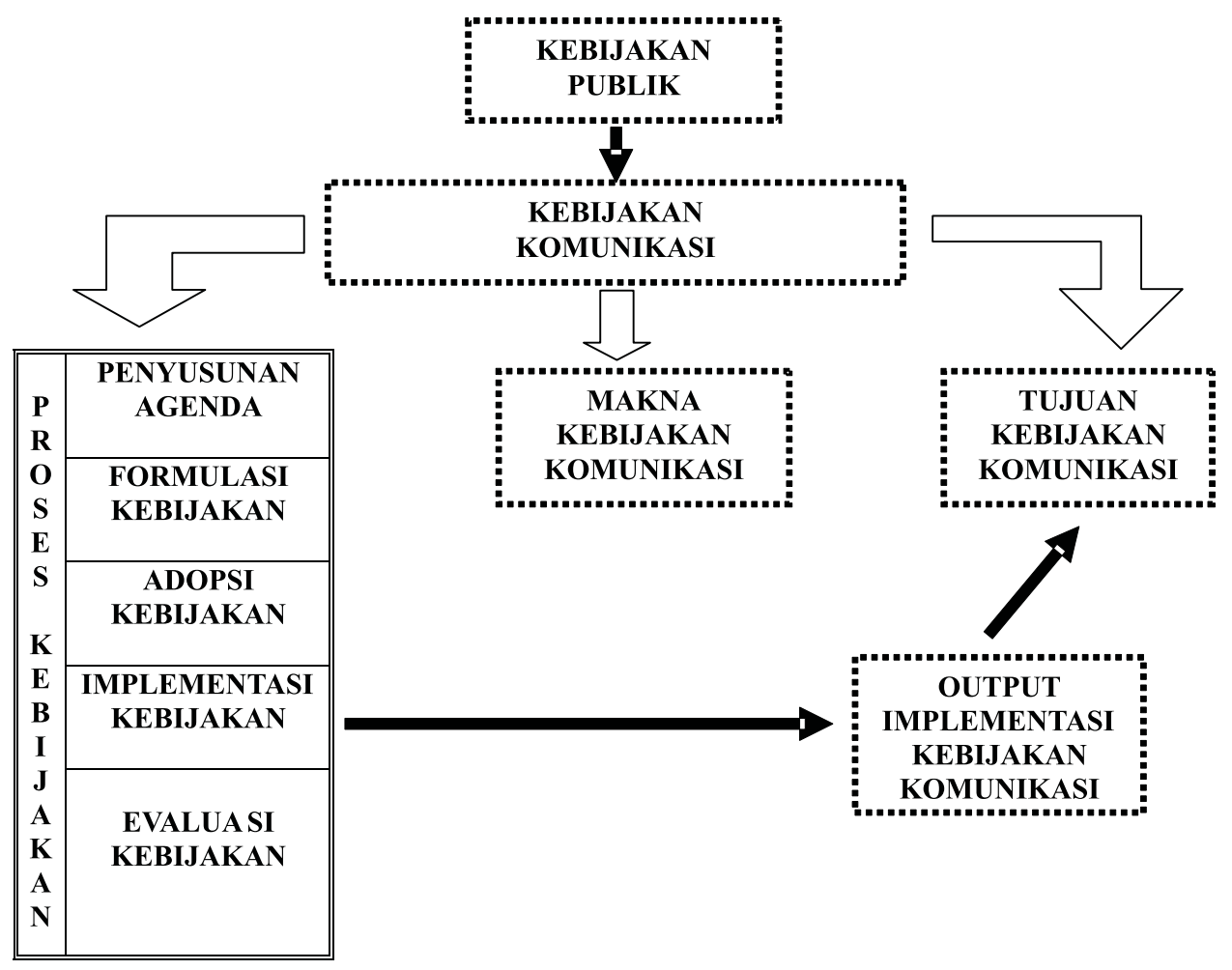

Bagan 2

Skema Kebijakan Komunikasi 


\section{Pembahasan}

Harus diakui implementasi UU No. 14 tahun 2008 tentang KIP ini sangat lambat hampir di seluruh Indonesia. Ada banyak faktor yang membuat lambatnya proses implementasi terutama tahap pada tahap praktik. Faktor tersebut yaitu faktor implementasi di lapangan dan faktor UU nya itu sendiri. Ringkasan singkat mengenai gambaran-gambaran faktor ini dapat dilihat dari tabel dibawah ini:

\begin{tabular}{|c|c|c|c|}
\hline No & Hal & Faktor di Lapangan & $\begin{array}{c}\text { Faktor UU dan aturan } \\
\text { pendukung }\end{array}$ \\
\hline 1. & Organ Pendukung & $\begin{array}{l}\text {-Pembentukan Komisi } \\
\text { Informasi yang masih sangat } \\
\text { lambat hampir di seluruh } \\
\text { Indonesia. } \\
\text { - PPID (Pejabat Pengelola } \\
\text { Informasi dan Dokumentasi) }\end{array}$ & $\begin{array}{l}\text { Masih belum detail pasalnya } \\
\text { yang mengatur tentang } \\
\text { Komisi Informasi Provinsi. } \\
\text { - UU dan Aturan Pendukung } \\
\text { tidak sinkron. }\end{array}$ \\
\hline 2. & $\begin{array}{l}\text { Proses dan } \\
\text { praktek }\end{array}$ & $\begin{array}{l}\text { Badan Publik masih } \\
\text { kebingungan praktek } \\
\text { pengelolaan informasi } \\
\text { khususnya pengujian } \\
\text { konsekuensi }\end{array}$ & $\begin{array}{l}\text { Pasal } 17 \text { tentang informasi } \\
\text { yang dikecualikan } \\
\text { berpeluang besar bersifat } \\
\text { pasal karet. }\end{array}$ \\
\hline 3. & $\begin{array}{l}\text { Budaya birokrasi } \\
\text { pemerintah }\end{array}$ & $\begin{array}{l}\text { Budaya kerja di birokrasi } \\
\text { pemerintah khususnya di } \\
\text { bidang transparansi dan etos } \\
\text { kerja masih rendah }\end{array}$ & $\begin{array}{l}\text { Istilah penunjukan PPID di } \\
\text { pasal } 13 \text { berpotensi membuat } \\
\text { kinerja tidak optimal. }\end{array}$ \\
\hline
\end{tabular}

Gambaran singkat mengenai tabel di atas dapat diuraikan secara berurutan sebagai berikut : pertama, persoalan organ pendukung merupakan persoalan yang pelik. Organ pendukung dalam konteks ini adalah Komisi Informasi di tingkat Provinsi maupun Pejabat Pengelola Informasi dan Dokumentasi. UU ini mengamanatkan dibentuknya Komisi Informasi di tingkat pusat, provinsi mauupun kabupaten (optional). Berdasarkan bab IV UU No.14 tahun 2008 mulai pasal 23 hingga pasal 46 mengenai Komisi Informasi, disebutkan fungsi, susunan, wewenang,tugas, pertanggung jawaban hingga proses penyelesaian sengketa informasi. Berdasarkan pasalpasal ini, peran Komisi Informasi sangat strategis dan penting karena komisi memiliki wewenang untuk memutuskan membuka atau menutup sebuah informasi dalam sengketa informasi. Begitu strategisnya posisi, peran dan wewenang Komisi Informasi ini membuat proses pembentukannya pun lambat. Sampai saat ini, praktis, kurang dari 10 provinsi saja di seluruh Indonesia yang sudah memiliki Komisi Informasi Provinsi. Provinsi DI Yogyakarta sendiri baru hingga pada tahap keluarnya nama-nama komisioner hasil fit and propertest DPRD namun itupun belum dilantik secara resmi. Belajar pada proses pembentukan KI Provinsi di DIY, patut dicermati dinamika faktor-faktor yang bisa menjadi pertimbangan mengapa proses pembentukan KI Provinsi sangat lambat. Kehadiran KI Provinsi dengan 
besarnya peran dan wewenang juga bisa sedikit mengusik badan publik karena harus segera menyiapkan dirinya. Jadi semakin lambat KI Provinsi terbentuk tentu semakin baik pula bagi badan publik.

Tataran UU juga menyimpan persoalan, misalnya, pada proses pengangkatan atau rekruitmen calon anggota KI Provinsi. Pasal 25 menyebutkan bahwa anggota KI Provinsi dan/ KI Kabupaten/Kota berjumlah 5 orang yang mencerminkan unsur pemerintah dan unsur masyarakat. Proses perekrutan untuk unsur masyarakat bisa dikatakan lebih rinci tahapannya tetapi untuk unsur pemerintah tidak jelas bagaimana prosesnya. Apakah ditentukan oleh pemerintah daerah atau tetap melewati tahapan layaknya unsur masyarakat. Pada bagian penjelasan juga tidak disebutkan secara jelas. Seharusnya ada aturan setingkat PP (Peraturan Pemerintah) yang mengatur hal ini karena defenisi "unsur pemerintah" juga memiliki tafsiran yang bermacammacam. Ada yang berpendapat harus PNS aktif namun ada juga yang berpendapat tidak harus PNS aktif melainkan orangorang yang tahu seluk beluk birokrasi meskipun bukan PNS aktif.

UU ini mengamanatkan di setiap badan publikharusmemilikiPPID(Pejabat Pengelola Informasi dan Dokumentasi). PPID ini bertugas dan bertanggung jawab di bidang penyimpanan, pendokumentasian, penyediaan, dan/ atau pelayanan informasi di badan publik. Artinya PPID merupakan ujung tombak di setiap badan publik untuk melayani permohonan informasi dari pemohon informasi publik. Tapi PPID di badan publik hingga 3 tahun setelah UU ini disahkan atau 1 tahun setelah UU ini resmi diberlakukan belum menunjukkan kinerja yang optimal. Contohnya di Provinsi DI Yogyakarta. PPID baru dibentuk Gubernur berdasarkan Keputusan Gubernur DIY No. 338/KEP/ 2010 tentang Pejabat Pengelola Informasi Dan Dokumentasi Daerah Gubernur Istimewa Yogyakarta. Keputusan ini menghasilkan PPID dijabat oleh Kepala Dishubkominfo DIY dibantu oleh PPID Pembantu di setiap badan publik di tingkat provinsi. Tapi belakangan pun formasi ini masih berpotensi berubah karena adanya ketidaksesuaian dengan Surat dari Kemendagri. Sejak dibentuk berdasarkan Keputusan Gubernur ini, PPID belum bisa menjalankan fungsinya secara optimal. Lagi-lagi alasan terbesar yaitu KI Provinsi yang belum dilantik hingga saat ini. Padahal KI Provinsi lah yang juga harus bertugas melakukan sosialisasi ke badan-badan publik.

PPID diatur dalam UU No. 14 tahun 2008 tentang KIP sebagai dasar hukum tertinggi. PPID kembali diperjelas dalam PP No. 61 tahun 2010 tentang Pelaksanaan Undang-Undang Nomor 14 tahun 2008 tentang Keterbukaan Informasi Publik yang juga membahas PPID di pasal 12, 13, 14,15. UU maupun PP ini menyebutkan bahwa PPID ditunjuk oleh pimpinan badan publik negara yang bersangkutan. PPID dalam menjalankan tugasnya dibantu oleh pejabat fungsional di badan publik yang bersangkutan. Ketidaksesuaian antar aturan hukum muncul ketika keluar Peraturan Menteri Dalam Negeri Nomor 35 tahun 2010 tentang Pedoman Pengelolaan Pelayanan Informasi Dan Dokumentasi Di Lingkungan Kementerian Dalam Negeri dan Pemerintah Daerah tertanggal 14 mei 2010.

Dalam Permendagri ini disebutkan bahwa PPID di lingkungan Kementrian Dalam Negeri dibantu oleh PPID 
Pembantu yang berada di lingkungan komponen dan/atau Pejabat fungsional. Artinya muncul istilah baru yaitu PPID Pembantu yang tidak disebutkan di dalam aturan hukum lebih tinggi seperti UU dan PP nya. Kembali mengambil contoh kasus Provinsi D.I. Yogyakarta, Permendagri No. 35 tahun 2010 ini direspon oleh Gubernur DIY dengan mengeluarkan Keputusan Gubernur DIY No. 338/KEP/ 2010 tentang Pejabat Pengelola Informasi Dan Dokumentasi Daerah Gubernur Istimewa Yogyakarta tertanggal 28 desember 2010. Keputusannya, PPID di Provinsi DIY dijabat oleh Kepala Dishubkominfo D.I.Yogyakarta dengan dibantu oleh PPID Pembantu yang dijabat sebagian besar oleh Sekretaris Dinas, Badan maupun Kepala Bagian di tingkat provinsi DIY. Sangat disayangkan, Provinsi DIY terlambat mendapatkan surat Menteri Dalam Negeri Republik Indonesia nomor 188.2/3435/Sj tentang Pelaksanaan Undang-Undang Nomor 14 tahun 2008 tentang KIP tertanggal 23 Agustus 2010 yang memutuskan ada 4 kategori penunjukkan dan Pengangkatan PPID. Provinsi D.I Yogyakarta termasuk dalam kategori c yaitu "bagi daerah yang memiliki Dinas Komunikasi dan Informatika dan juga memiliki Biro/ Bagian Humas, mengingat pelayanan informasi merupakan fungsi komunikasi atau hubungan masyarakat, Kepala Biro/ Bagian Humas ditunjuk dan diangkat sebagai PPID". Surat Menteri Dalam Negeri ini baru didapatkan pada 2011 dimana Keputusan Gubernur sudah dikeluarkan terlebih dahulu. Artinya Keputusan Gubernur ini berpotensi mubazir karena tidak sesuai dengan Surat Menteri Dalam Negeri tersebut.

Kedua, persoalan praktik UU No. 14 tahun 2008 tentang KIP ini di lapangan juga tersendat. Harus diakui, begitu besarnya implikasi UU ini membuat badan publik bersikap hati-hati dan menunggu. Terutama di daerah-daerah yang belum memiliki KI Provinsi, kecendrungan untuk bergerak melambat semakin menguat. Kehati-hatian badan publik dalam mempraktekkan UU ini juga dipengaruhi masih terdapat kebingungan secara teknis operasional. Memang KI Pusat sudah mengeluarkan Peraturan KI No. 1 tahun 2010 tentang Standar Layanan Informasi Publik sebagai petunjuk teknis. Dalam sosialisasi peraturan berbentuk buku ini juga sudah dicantumkan prosedurnya, jenis-jenis standar layanan informasi publiknya hingga lampiran-lampiran yang harus dibuat badan publik. Tetapi dipastikan masih ada kebingungan dari badan publik. Hal yang paling sederhana adalah uji konsekuensi dalam penentuan layak tidaknya sebuah informasi diberikan kepada publik/pemohon informasi publik. Berdasarkan UU di pasal 19, tugas ini dijalankan oleh PPID badan publik dimana PPID wajib melakukan pengujian tentang konsekuensi terkait informasi yang dikecualikan sebelum memutuskan memberikan atau tidak sebuah informasi publik. Alasan untuk menerima dan menolak ini pun harus disampaikan secara tertulis di dalam jawaban badan publik atas permohonan pemohon informasi publik. Tetapi uji konsekuensi ini bisa menjadi sangat subyektif apalagi berdasarkan pasal 17 tentang informasi yang dikecualikan yang bersifat multitafsir. Kedalaman pertimbangan juga bisa menjadi permasalahan tersendiri. Hal ini tentu saja berkaitan dengan budaya transparansi badan publik itu sendiri nantinya.

Faktor isi pasal UU ini menjadi isu krusial khususnya pasal 17 tentang informsi yang dikecualikan. Kita ingat 
kasus rekening gendut POLRI yang akhirnya diputuskan harus dibuka berdasarkan keputusan Komisi Informasi Pusat. Artinya, informasi yang dianggap berbahaya atau membahayakan badan publik, pimpinan atau orang-orang di dalamnya menjadi sangat rentan untuk ditutup. Pasal 17 memang sudah menyebutan informasi apa saja yang dikecualikan untuk dibuka. Informasi tersebut meliputi informasi yang jika dibuka dapat menghambat proses penegakan hukum, dapat mengganggu kepentingan perlindungan hak atas kekayaan intelektual dan perlindungan dari persaingan usaha tidak sehat, informasi yang membahayakan pertahanan dan keamanan negara, mengungkapkan kekayaan alam indonesia, merugikan ketahanan ekonomi negara, informasi yang dapat merugikan kepentingan hubungan luar negeri, informasi yang dapat mengungkapkan isi akta otentik yang bersifat pribadi dan kemauan terkahir ataupun wasiat seseorang, dan informasi yang dapat mengungkapkan rahasia pribadi seseorang. Pasal ini masih sangat lentur untuk dipraktekkan. Penentuan sebuah informasi termasuk dalam kategori dikecualikan bisa saja bukan karena pertimbangan bahaya sebuah negara atau kerugian ekonomi, atau lain hal tetapi karena ada sebuah kejahatan yang harus ditutupi. Sekedar contoh, informasi mengenai kekayaan alam indonesia. Informasi ini tentu masih bisa diperdebatkan apakah perlu dibuka atau tidak. Jika saja kita dapat mengetahui berapa kekayaan tambang di Indonesia mungkin kita bisa menghitung berapa sebenarnya pendapatan yang harusnya diterima negara, berapa pajak yang harus dibayarkan oleh perusahaan tambang tersebut, apakah sudah sesuai dengan kenyataan atau masih banyak pajak negara yang dikemplang oleh wajib pajak. Atau misalnya informasi berapa hasil kekayaan minyak kita. Apakah benar kita terbebani dengan subsidi BBM? Berapa barel sebenarnya hasil minyak bumi kita? Jika dikalikan dengan harga minyak mentah dunia dikurangi dengan biaya impor minyak untuk menutupi kekurangan konsumsi minyak dalam negeri, berapa sebenarnya sumbangan minyak bumi untuk APBN kita? Mungkin kita bisa mengetahui jawaban apakah kita perlu menaikkan harga BBM atau bahkan kita bisa tahu dimana celah permainan mafia terkait pertambangan. Namun pemerintah lebih memilih untuk menutup informasi ini.

Ketiga, budaya kerja khususnya budaya birokrasi pemerintah tak bisa disepelekan begitu saja. Harus diakui budaya kerja terutama etos kerja dan transparansi birokrasi pemerintah masih rendah. Masalah transparansi sudah disinggung sedikit di atas. Pemerintah lebih memilih menutup informasi yang sebenarnya masih perlu dan penting untuk diketahui. Misalnya, informasi mengenai kekayaan alam Indonesia. Transparansi merupakan salah satu tujuan dari keterbukaan informasi publik atau kebebasan informasi. Kebebasan informasi juga berkait dengan ciri negara demokrasi yang memerlukan ketersediaan informasi yang sempurna/ bulat karena ruang rahasia negara, rahasia korporat, dan rahasia pribadi perlu menyempit, dan ruang informasi publik melebar.(Amirudin, 2009).

Syarat ini tentu berbeda dengan ciri negara otoritarianisme dimana diperlukan perlindungan terhadap negara, korporat, dan pribadi yang sama sama kuat sehingga diperlukan informasi rahasia sebanyak-banyaknya. Pergulatan antara kebebasan informasi di Indonesia 
semakin menguat ketika pemerintah berinisiatif mengajukan RUU Rahasia Negara. Sebagian pihak menduga, RUU ini merupakan respon pemerintah terhadap keluarnya UU KIP ini. Merasa sedikit terusik karena diminta untuk lebih transparan, pemerintah berusaha menutup informasi kembali. Artinya, pemerintah bukan saja belum siap untuk bersikap transparan di level praktek namun di level wacana tampakanya pemerintah juga tidak terlalu mau untuk menuruti amanat UU ini.

Selain budaya tranparan yang belum menjadi kesadaran, nilai etos kerja juga patut diperhatikan. UU ini menuntut para badan publik untuk bekerja secara profesional, teliti, dan tranparan. Artinya ada beban tambahan yang diberikan kepada badan publik, katakanlah para PNS. Para PNS terutama yang ditunjuk menjadi PPID memiliki pekerjaan tambahan untuk melaksanakan UU KIP ini. Padahal semangat atau etos kerja birokrasi pemerintah kita selama ini masih belum memuaskan apalagi ditambah dengan pekerjaan baru. Salah satu alasan yang masuk akal adalah PPID ditunjuk bukan diangkat. Seorang PPID ditunjuk dari badan publik. Artinya seseorang yang akan menjabat PPID sebelumnya sudah memiliki jabatan dan pekerjaan dan ketika ia ditunjuk sebagai PPID maka pegawai tersebut memiliki pekerjaan tambahan yang sangat memungkinkan jabatan PPID ini menjadi pekerjaan "sekedar" saja.

UU No. 14 tahun 2008 tentang KIP di pasal 13 ayat 1 menyebutkan bahwa "Untuk mewujudkan pelayanan cepat, tepat, dan sederhana setiap badan publik menunjuk Pejabat Pengelola Informasi dan Dokumentasi." Peraturan Menteri Dalam Negeri Nomor 35 tahun 2010 tentang Pedoman Pengelolaan Pelayanan
Informasi Dan Dokumentasi Di Lingkungan Kementrian Dalam Negeri dan Pemerintah Daerah tertanggal 14 mei 2010 menyebutkan PPID dibantu oleh PPID Pembantu. Dalam kasus Provinsi D.I.Y, Gubernur D.I.Y mengeluarkan susunan PPID dan PPID Pembantu. Hal ini juga berpotensi melanggar UU. Selain tidak ada istilah PPID Pembantu dalam UU nya, dengan adanya formasi PPID Pembantu bisa membuat proses menjadi lebih panjang bagi pemohon informasi publik. Sekedar contoh, bila ada sebuah informasi di suatu dinas yang dijabat PPID Pembantu (konteks D.I.Y) belum terklasifikasikan sebagai informasi yang bisa diberikan atau berstatus sebagai informasi yang dikecualikan maka akan berpotensi terjadi pelimpahan kepada PPID sebagai tingkatan yang lebih tinggi. Harapannya, PPID lah yang memutuskan. Kemudian PPID baru akan memberikan jawaban kembali kepada PPID Pembantu untuk "mengeksekusi" informasi tersebut untuk diberikan atau ditolak. Artinya, proses menjadi lebih panjang, rumit dan jelas memakan waktu yang lebih lama. Padahal di pasal 2 UU No. 14 tahun 2008 tentang KIP disebutkan bahwa setiap informasi publik harus dapat diperoleh setiap Pemohon Informasi Publik dengan cepat dan tepat waktu, biaya ringan, dan cara sederhana. Dengan etos kerja birokrasi pemerintah yang masih rendah ditambah formasi yang tidak sepenuhnya sesuai dengan amanat UU maka akan berpotensi terjadi pelanggaran UU khususnya dalam semangat mewujudkan pelayanan cepat, tepat, dan sederhana.

\section{Penutup}

Keterbukaan Informasi Publik merupakan satu hal yang penting. Penting karena ada beberapa alasan yang bisa disampaikan. Pertama, Kebebasan 
informasi merupakan salah satu HAM dimana setiap orang berhak dan bebas untuk mendapatkan informasi. Kedua, Kebebasan Informasi merupakan salah satu ciri demokrasi dimana rahasia negara, korporat, dan pribadi perlu menyempit, dan ruang informasi publik seharusnya mendapatkan porsi yang lebih besar. Ketiga, Kebebasan Informasi Publik akan menghadirkan tranparansi yang pada akhirnya semakin mendorong partisipasi masyarakat dalam pembangunan. Logikanya, semakin banyak masayarakat tahu tentang informasi tentang halhal yang berkaitan dengan hajat hidup mereka entah itu kebijakan maupun anggaran maka semakin mereka ingin berpartisipasi minimal sebagai pengawas kinerja aparat-aparat negara yang mengurus mereka. Terakhir, semakin gencarnya informasi dan semakin banyaknya perputaran informasi maka masyarakat bergerak menuju ke arah bentuk masyarakat informasi.

Pemerintah bersama DPR memang akhirnya menyepakati disahkannya UU No. 14 tahun 2008 tentang KIP ini. Tetapi sebagai sebuah produk, UU ini juga tak lepas dari kritik baik dari sisi isi UU nya maupun pelaksanaannya setidaknya hingga saat ini. Dari sisi isi teks, UU ini masih menyimpan persoalan yang sangat berpotensi untuk menghadirkan konflik ke depannya. Pasal karet yang menjadi ciri hampir di seluruh UU Indonesia menjadi persoalan yang serius di UU. Pasal 17 tentang informasi yang dikecualikan menjadi isu yang kritis karena bisa menjadi "andalan" bagi badan publik untuk menolak pemohonan dari pemohon badan publik. Kekhawatirannya adalah alasan untuk menolak sebuah permohonan informasi bukan karena murni informasi tersebut benar-benar dikecualikan melainkan karena ada sebuah kejahatan yang harus ditutupi. Di sisi implementasi, persoalan juga tak kalah kompleks. Keselarasan dengan aturan penjelas di bawahnya juga menyimpan persoalan yang meskipun kecil pergeserannya namun bisa berdampak besar pada pelaksanaannya. Implementasi dengan terbentuknya organ-organ penting khususnya KI Provinsi juga menjadi perhatian serius karena hampir sebagian besar provinsi di Indonesia belum memiliki KI Provinsi masing-masing. Sederhananya, keseriusan pemerintah dalam hal ini badan publik patut dipertegas kembali apakah mereka benar-benar serius untuk memulai sikap dan budaya transparan atau masih sekedar saja.

Terakhir, kebijakan komunikasi sebagai sebuah perspektif ilmu komunikasi mencoba untuk menawarkan pengetahuan yang pada akhirnya bisa menghadirkan kesadaran bagi masyarakat untuk lebih cerdas menyikapi sebuah kebijakan. Tentu saja karena sebuah kebijakan di bidang apa saja termasuk kebijakan komunikasi bisa saja dianggap sebagai sebuah pesan (message/ says what) dari pemerintah (who) kepada masyarakat (to whom) yang disampaikan melalui sosialisasi dengan cara apa saja (in which channel) dengan efek yang mengikat (with what effect).

\section{DAFTAR PUSTAKA}

Abrar, Ana Nadya, 2008, Kebijakan Komunikasi : Konsep, Hakekat dan Praktek. Yogyakarta: Penerbit Gaya Media.

Anderson, James E, 1984, Public Policy Making. Holt, Rinehart and Winston. New York

Agustino, Leo, 2008, Dasar-Dasar Kebijakan Publik. Bandung: CV 
Alfabeta Bandung

Dunn, William N, 1999, Pengantar Analisis Kebijakan Publik.(edisi ke-2). Yogyakarta. Gadjah Mada University Press.

Dye,Thomas, 1995, Understanding Public Policy. New Jersey : Prentice Hall.

Friedrich, Carl J.1969. Man and His Government.New York: Mc Graw Hill.

Nugroho, Riant. 2008. Public Policy. Jakarta:PT. Elex Media Komputindo. Rose Richard (ed).1969. Policy Making in Great Britain. London: McMillan.
Siregar, Ashadi, 1998, "UK adalah Media".dalam Salam Aprinus (Editor), Umar Kayam dan Jaring Semiotik.Yogyakarta: Pustaka Pelajar.

Subarsono, AG. 2005, Analisis Kebijakan Publik. Konsep,Teori dan Aplikasi. Yogyakarta: Pustaka Pelajar.

Winarno, Budi, 2007, Teori dan Proses

Kebijakan Publik. Yogyakarta : Media Pressindo.

Widodo, Joko, 2007, “Analisis Kebijakan Publik" Konsep dan Aplikasi Analisis Proses Kebijakan Publik. Bayumedia Publishing: Malang. 


\title{
Sistem Kendali dan Strategi Penanganan (Manajemen) Krisis Dalam Kajian Public Relations
}

\author{
Arief Fajar \\ Program Studi Komunikasi, Universitas Muhammadiyah Surakarta
}

\begin{abstract}
The role of Public Relations, especially in aspects of management (Public Relations Management) to handle issues and crises will greatly depend on the type and systems as an organization. According to Anne Gregory at least in Crisis Management, PR is able to communicate to management about the structure of stakeholder from organizations and their characteristics which are expected to support the policy.
\end{abstract}

Keywords: Crisis Management and Public Relations

“Kita Semua Membenci Krisis" (Kasali, 1995: 219)

\section{Pendahuluan}

Sebagian orang memahami Public Relations sebagai aktifitas, sebagian yang lain mengatakan sebagai sebuah profesi. Bahkan ada yang memahami sebagai sebuah institusi (terlembaga) seperti divisi, bagian, departemen, dan biro jasa, hal ini tidak sepenuhnya benar, tetapi juga tidak sepenuhnya salah. Namun akan menjadi persoalan ketika kita berdebat bagaimana sebenarnya bentuk, fungsi, macam dari Public Relations, terlebih untuk membedakan yang mana Public Relations dan bukan Public Relations. Pada muaranya dapat kita simpulkan; untuk melihat keberadaan Public Relations (apakah sudah menerapkan Public Relations atau tidak) dalam sebuah lembaga atau organisasi, kita tidak dapat memberikan ukuran dengan adanya bagian khusus yang menangani aktifitas Public Relations. Ukuran tersebut harus diperluas yaitu sejauh mana organisasi menerapkan fungsi Public Relations secara sistematis.

Padahal, Public Relations atau dalam bahasa awam di Indonesia dipadankan dengan istilah Hubungan Masyarakat, menjadi katarsis mempercepat pembentukan image berbagai kancah bidang. Sebagai contoh; panggung politik, seseorang calon legislator atau pemimpin memerlukan backup peran Public Relations semisal hubungan media (media relations). Hal ini menunjukkan perkembangan Public Relations terjadi persilangan dengan berbagai hal atau subtansi kajian.Bahkan dalam bidang pemasaran, terjadi perpaduan atau bauran yang diperkirakan mematikan unsur pemasaran kontemporer yaitu periklanan. Mari lihat buku karya Al dan Laura Ries, "The Fall of Advertising and The Rise of Public Relations"; memperlihatkan kekuatan Public Relations bukan hanya pada aspek pembentukan citra tetapi 
juga pemasar baik secara sosial maupun keuntungan semata. Sehingga, praktisi dan pengkaji Public Relations dengan gamblang dapat mengatakan Public Relations merupakan bagian terpenting dalam membangun, merawat dan melestarikan sebuah organisasi; bukan lagi penutup kaca cacat organisasi atau pencipta citra.

Dari berbagai rangkuman sumber; baik Cutlip dan Jefkins menyebutkan urgensi keberadaan Public Relations sebagai berikut;

a. Mengkomunikasikan Kebijakan

b. Membangun hubungan efektif melalui komunikasi dan persuasi kepada publik internal maupun publik eksternal

c. Menjawab tantangan perubahan manajemen modern kepuasan publik sebagai pasar

d. Membantu organisasi keluar dari krisis dengan penerapan manajemen krisis (Cutlip, Center, Broom, 2007 dan Frank Jefkins, 2003)

Lalu pertanyaan selanjutnya justru bukan pada bagaimana Public Relations membangun dan merawat institusi. Namun, bagaimana sebuah organiasi mampu dilindungi oleh Public Relations sebagai sistem kendali krisis? Hal inilah yang menjadi acuan penulisan artikel ini.

\section{Selayang Pandang Public Relations}

Sementara ini, banyak sekali definisi tentang Public Relations, dalam tulisan ini, definisi yang akan dijadikan patokan tentu terkait dengan Public Relations dalam lembaga pemerintahan. Sebelumnya, mari kita tarik sebuah pemahaman bersama tentang definisi Public Relations; secara garis besar hanya ada dua kutub terkait konsep Public Relations yang ada di dunia ini yaitu;

a. Versi Amerika dimotori oleh PRSA (Public Relations Society of America); Public Relations dipahami sebagai fungsi manajemen yang membangun dan mempertahankan hubungan yang baik dan bermanfaat antara organisasi dengan publik yang mempengaruhi kesuksesan atau kegagalan organiasi tersebut. (Cutlip et al, 2007: 6).

b. Sedangkan versi Britania (secara luas Anglo Saxon) dimotori oleh IPR (Institute of Public Relations), salah satunya Frank Jefkins; Public Relations diartikan sebagai bentuk komunikasi yang terencana, baik ke dalam maupun ke luar, antara suatu organisasi dengan semua khalayaknya dalam rangka mencapai tujuan spesifik yang berlandaskan pada saling pengertian (Jefkins et al, 2003: 10)

Sehingga, berkaca dari dua versi tersebut keberadaan Public Relations dalam sebuah organisasi sangat ditentukan oleh bagaimana manajemen organisasi itu dalam memahami urgenitas membangun hubungan sinergis dengan publiknya. Pada muaranya dapat kita simpulkan; untuk melihat keberadaan Public Relations (apakah sudah menerapkan Public Relations atau tidak) dalam sebuah lembaga atau organisasi, kita tidak dapat memberikan ukuran dengan adanya bagian khusus yang menangani aktifitas Public Relations. Ukuran tersebut harus diperluas yaitu sejauh mana organisasi menerapkan fungsi Public Relations secara sistematis. Dalam amatan penulis; hal ini sangat ditentukan oleh tipe dan sistem dari sebuah organisasi itu sendiri.

Pada tipe sistem organisasi yang tertutup; fungsi Public Relations bukan bagian yang dominan dan hanya menjadi pelaksana keputusan manajemen. Hal ini 
diasumsikan; Public Relations mempunyai kewenangan terbatas dalam manajemen untuk mempengaruhi lingkungan organisasi dan manajemen organisasi sendiri yang mempunyai kewenangan utama dalam melakukan hal tersebut.

Sedangkan, tipe dan sistem organisasi yang terbuka Public Relations dalam tipe organisasi ini menjalankan peran utama sebagai mediator atau komunikasi yang resiprokal antara organisasi dengan publiknya.

\section{Komunikasi Krisis dalam Kajian Public Relations serta Strategi Penanganan (Manajemen) Krisis}

Ada beberapa hal mendasar mengenai definisi Manajemen Krisis dalam kajian Public Relations, yaitu;

Grapevine (desas desus) atau isu merupakan "komunikasi informal" yang berasal atau bersentral dari hal-hal urgen bagi organisasi, sedangkan secara etimologis, krisis (crisis) berasal dari bahasa Yunani yaitu kata krinein berarti keputusan (Kamus Webster Online Dictionary, 2005, www.merriamwebster.com, diakses 4 September 2010)

Secara terminologi; krisis adalah malapetaka yang dapat muncul secara alami, hasil kesalahan, intervensi, niat jahat. (Argenti, 2009: 31). Sehingga apabila kita tarik sebuah rumusan maka, krisis dapat diakibatkan (di-brakedown) karena dua hal yaitu;

a. Secara alamiah, semisal; bencana alam

b. Akibat kesalahan manusia (human error), semisal; keteledoran, intervensi, dan sebagainya.

A point of great difficulty or danger to the organization, possibly threatening its existence and continuity, and that requires decisive change. (Cornelissen,
2004: 186)

Suatu titik kesulitan atau bahaya bagi organisasi, dapat mengancam keberadaan dan kesinambungan, dan membutuhkan perubahan yang tepat. Sehingga, maksud dari manajemen isu krisis adalah perencanaan, strategi menangani kondisi urgen yang melanda sebuah organisasi baik bersifat alamiah ataupun human error.

Dalam kajian Public Relations, komunikasi krisis merupakan bagian tindakan Public Relations yang terukur untuk menanggapi sebuah situasi krisis yang dapat menghancurkan reputasi sebuah perusahaan atau disebut Public Relations Krisis (crisis public relations). Istilah ini (crisis public relations) pertama kali digunakan Edward Bernays dalam menanggapi tuduhan kepada Standard Oil. (Biagi, 2010: 295).

Sedangkan menurut Anne Gregory setidaknya dalam Risk and Crisis Management, humas mampu mengkomunikasikan kepada manajemen organisasi tentang gambaran stakeholder dan karakteristiknya dimana diharapkan dukungan terhadap kebijakan tersebut.

Konsep mengenai definisi manajemen krisis berimplikasi dalam strategi manajemen krisis dalam kajian Public Relations. Salah satunya model strategi manajemen krisis dari Rhenald Kasali (1995: 225-230), yang mengadaptasi model anatomi krisis Steven Fink, sebagai berikut:

a. Tahap Prodomal

Tahap prodomal sering disebut pula warning stage karena ia memberi sirine tanda bahaya mengenai sintomsintom yang harus segera diatasi. Mengacu pada definisi krisis, tahap ini juga merupakan bagian dari 
turning point bila manajemen gagal mengartikan atau menangkap signal ini, krisis akan bergeser ke tahap yang lebih serius: tahap akut. Sering pula tahap prodomal sebagai tahap sebelum krisis atau precrisis. Tetapi sebutan ini hanya dapat dipakai untuk melihat krisis secara keseluruhan dan disebut demikian setelah krisis memasuki tahap akut sebagai retrospeksi.

b. Tahap Akut

Inilah tahap ketika orang mengatakan : "telah terjadi krisis". Meski bukan disini awal mulanya krisis, orang menganggap suatu krisis dimulai dari sini karena gejala yang samar-samar atau sama sekali tidak jelas itu mulai kelihatan jelas. Dalam banyak hal, krisis yang akut sering disebut sebagai the point of no return. Artinya, sekali signal-signal yang muncul pada tahap peringatan atau prodomal stage tidak digubris, ia akan masuk ke tahap akut dan tidak bisa kembali lagi. Kerusakan sudah mulai bermunculan, reaksi mulai berdatangan, dan isu menyebar luas.

Namun, beberapa kerugian lain yang akan muncul amat bergantung dari aktor yang mengendalikan krisis. Salah satu kesulitan besar dalam menghadapi krisis pada tahap akut sekalipun sangat siap adalah intensitas dan kecepatan serangan yang datang dari berbagai pihak yang menyertai tahap ini. Kecepatan ditentukan oleh jenis krisis yang menimpa perusahaan, sedangkan intensitas ditentukan oleh kompleksnya permasalahan. Tahap akut adalah tahap antara, yang paling pendek waktunya bila dibandingkan dengan tahap lainnya. Bila ia lewat, maka umumnya akan segera memasuki tahap kronis. c. Tahap Kronik

Tahap ini sering juga disebut sebagai the clean of phase atau the post mortem. Sering pula tahap ini disebut sebagai tahap recovery atau self analysis. Di dalam perusahaan, tahap ini ditandai dengan perubahan struktural baik penggantian manajemen, penggantian pemilik, memasukkan nama-nama baru sebagai pemilik atau dilikuidasi. Crisis manager harus mampu memperpendek tahap ini karena semua orang sudah merasa letih, juga pers sudah mulai bosan memberitakan kasus ini. Namun, yang paling penting adalah perusahaan harus memutuskan mau hidup terus atau tidak. Kalau ingin hidup terus tentunya ia harus sehat dan mempunyai reputasi yang baik. Tahap kronik adalah tahap yang terenyuh. Kadang-kadang dengan bantuan konsultan krisis yang handal, perusahaan akan memasuki keadaan yang lebih baik, sehingga pujian berdatangan dan penyembuhan atau resolution mulai berlangsung.

d. Tahap Resolusi atau (Penyembuhan)

Tahap ini adalah tahap penyembuhan atau pulih kembali dan tahap terakhir dari empat tahap krisis. Meski bencana besar dianggap sudah berlalu, crisis manager tetap perlu berhati-hati, karena riset dalam kasus-kasus krisis menunjukkan bahwa krisis tidak akan berhenti begitu saja pada tahap ini. Krisis umumnya berbentuk siklus yang akan membawa kembali keadaan semula atau prodomal stage.

Masing-masing tahap tersebut saling berhubungan dan membentuk siklus. Lamanya masing-masing tahap itu sangat bergantung pada sejumlah variabel, siklus krisis berpola dapat dilihat dalam 
bagan berikut ini :

\section{Contoh Kasus; Analisa Sistem Kendali dan Strategi Penanganan (Manajemen) Krisis PT Newmont Minahasa Raya ${ }^{1}$}

PT Newmont Minahasa Raya (NMR) mempunyai sistem kendali dan mengembangkan strategi penanganan krisis dengan beberapa pendekatan. Salah satunya akan penulis analisis berdasarkan model strategi manajemen krisis dari Rhenald Kasali (adaptasi model anatomi krisis Steven Fink), sebagai berikut;

\section{a. Tahap Prodomal}

Kegagalan NMR mendeteksi tandatanda akan adanya isu-isu ditahap awal, dan untuk tidak membiarkan isu-isu berkembang menjadi krisis terutama krisis lingkungan, yaitu;

- Prosedur dan lokasi Sistem Pembuangan Tailing Dasar Laut (SPDTL) yang berada di lapisan awal zona termoklin yaitu pada kedalaman 82 (delapan puluh dua) meter. Padahal sesuai analisa dampak lingkungan, lokasi pembuangan limbah harus sedalam 150 meter di bawah termoklin.

- Pembuangan tailing yang salah, menyebabkan kerusakan ekosistem laut berupa:

i. Kekeruhan yaitu pada zona euphotic, di mana pada zona tersebut terdapat lingkungan fitoplankton (produsen) yang butuh sinar matahari sebagai proses fotosintesis;

1 Berdasarkan kajian dan adaptasi tulisan Ulul Azmi, dkk, 2009, Peranan Public Relations dalam Menangani Krisis Lingkungan (Study Kasus: Pencemaran Teluk buyat), Materi Presentasi Kuliah pada Program Magister Ilmu Komunikasi-Sekolah Pascasarjana Universitas Sahid Jakarta, http://www. scribd.com/doc/27620791/Management-PublicRelation-Presentasi-Penanganan-Krisis-KasusTeluk-Buyat-Indonesia\#source:facebook, Diakses 4 September 2010. ii. Penurunan jumlah dan kualitas keberadaan terumbu karang di Teluk Buyat;

iii. Bioakumulasi (penumpukan terus menerus di dalam tubuh mahkluk hidup) dari sedimen pada biota laut di daerah euphotic;

iv. Penurunan kandungan bentos dan plankton (fitoplankton dan zooplankton) akibat tingginya kadar Arsen (As) pada sedimen di Teluk Buyat; dan Kematian ikan dalam jumlah lebih dari 100 (seratus) ekor di sekitar pipa pembuangan tailing di Teluk Buyat maupun terdampar di pantai

v. Kesehatan masyarakat Buyat yang menurun dan berbagai macam penyakit menyerang tubuh mereka, akibat konsumsi air minum dan ikan yang mengandung logam berat (As dan Mn).

- Tidak adanya surat ijin dari Kementerian Lingkungan Hidup

- Dalam pembuangan limbah ke laut maupun pengolahan limbah (B3)

b. Tahap Akut

Periode Krisis Akut benar-benar terjadi, Komunikasi adanya krisis yang ditempuh PT Newmont Minahasa Raya dalam menangani kasus pencemaran di Teluk Buyat tidak mengindahkan konsep-konsep komunikasi yang baik sehingga dapat dikatakan komunikasi korporat perusahaan pertambangan emas ini tidak berhasil. Adanya keterlambatan dalam mengambil keputusan yang dilakukan PT. NMR dalam menerapkan komunikasi sejak awal, yaitu ketika media memberitakan masalah dugaan pencemaran Teluk Buyat oleh PT. NMR pada Juli 2004. 
Komunikasi tentang krisis yang semestinya ditempuh harus bersifat proaktif dan tidak defensif. Selanjutnya, petugas Public Relation juga harus digunakan dalam mencapai solusi dan juga harus melakukan pendekatan Community Relations. Selain itu, penyelesaian krisis PT. NMR tidak melewati tahap pengumpulan pendapat dan keterlibatan masyarakat juga melihat belum adanya manajemen komunikasi krisis dalam penyelesaian kasus pencemaran Teluk Buyat.

c. Tahap Kronik

Strategi Penanganan krisis NMR, diantaranya;

- Strategi terkait dengan Kebijakan Pemerintah

i. PT. NMR, Berusaha untuk meminta pemerintah agar menata kesesuaian kebijakan antara pusat dengan daerah.

ii. Bersama-sama membantu pemerintah untuk proses pendanaan dalam melaksanakan pengawasan dan pembinaan Teluk Buyat.

iii. Bersama-sama pemerintah, membuat sebuah peraturan yang jelas, untuk pemantauan lingkungan dan pengkajian ulang mekanisme izin pembuangan tailing ke laut, serta mekanisme pemberian rekomendasi.

iv. Meminta pemerintah untuk mempublikasikan tindaklanjut izin pengolahan limbah terkait AMDAL, sehingga kedepannya diharapkan tidak ada lagi, kesimpangsiuran, dan dis-orientasi kepada pihak investor, yang ingin menginvestasikan dananya di Indonesia. v. Meminta pemerintah untuk membuat peraturan di masa mendatang, mampu menjelaskan jenis limbah dan peraturan yang terkait, serta membuat laboratorium yang memiliki kemampuan untuk menunjang dalam analisis.

vi. Menyarankan kepada pemerintah, untuk segera mempublikasikan hasil temuan kepada masyarakat, sehingga diharapkan masyarakat dapat memperoleh informasi yang benar terkait dengan kasus teluk Buyat ini.

- Strategi terkait dengan Masyarakat

i. Skala Lokal

$\checkmark$ Berupaya untuk membersihkan laut yang tercemar, agar membantu kesejahteraan masyarakat di teluk Buyat kembali bangkit.

$\checkmark$ Ikut memantau lingkungan dan sumber makanan sekitar teluk Buyat, dan berusaha proaktif mengevaluasi indikasi pencemaran lingkungan, lalu ikut serta dalam proses memperbaiki lingkungan masyarakat sekitar.

$\checkmark$ Mengadakan pengobatan gratis bagi masyarakat sekitar teluk Buyat.

$\checkmark$ PT. NMR berencana di tahun 2010, untuk menanam massal tanaman Mallee, di sekitar pesisir Teluk Buyat, dengan tujuan untuk mereduksi karbon, merkuri dan zat tercemar di laut lainnya. (suara batu hijau Edisi XIII - 2009).

ii. Skala Nasional

Ikut mendanai / mensponsori kegiatan promosi pariwisata 
Teluk Buyat dengan mengikut sertakan peserta dari seluruh Indonesia.

$\checkmark$ Ikut mensponsori kegiatan penyelaman nasional di Teluk Buyat.

- Strategi terkait dengan Sponsorship dan Publikasi

i. PT. NMR mengadakan kegiatan sponsorship berbagai kegiatan lingkungan, contohnya: Seminar Nasional Biologi Tahunan, Penanaman sejuta pohon,

ii. PT NMR ikut berpartisipasi dalam kegiatan pameran lingkungan.

iii. PT NMR ikut berpartisipasi dalam kegiatan promosi Pariwisata Sulawesi Utara.

iv. PT. NMR mempublikasikan kegiatan-kegiatan yang terkait dengan "kepedulian terhadap lingkungan".

- Strategi terkait dengan Riset

PT. NMR memberikan kesempatan kepada berbagai laboratorium, untuk melakukan pengujian terkait pencemaran zat di Teluk Buyat.

\section{d. Tahap Resolusi atau (Penyembuhan)}

Pelajaran yang dapat dipetik dari krisis teluk Buyat ini untuk kedepannya, supaya NMR dapat mendeteksi tandatanda akan adanya isu-isu ditahap awal, dan untuk tidak membiarkan isuisu berkembang menjadi krisis. Untuk NMR supaya lebih paham bahwa masyarakatpun mengalami perubahanperubahan, dimana secara demokratis mereka dapat menyuarakan serta mengekspresikan isi suara hati mereka, terutama jika menyangkut kesejahteraan rnasyarakat. Untuk supaya NMR lebih mengerti bahwa setiap stakeholder mempunyai agenda masing-masing. Oleh karena itu selain re-active, NMR dituntut untuk lebih pro-active, selalu dalam keadaan siap. Untuk menghadapi krisis, diperlu perencanaan yang matang, oleh karena hal itu expect the unexpected.

Masing-masing tahap di dalam krisis PT. NMR dan membentuk siklus, dapat dilihat dalam bagan berikut ini;

\section{Simpulan}

Dari beberapa pemaparan paper masih banyak kekurangan. Namun dapat ditarik kesimpulan tentang gambaran komunikasi krisis dalam kajian Public Relations mengenai sistem kendali dan mengembangkan strategi penanganan (manajemen) krisis, sebagai berikut ;

Dalam kajian Public Relations, komunikasi krisis merupakan bagian tindakan Public Relations yang terukur untuk menanggapi sebuah situasi krisis yang dapat menghancurkan reputasi sebuah perusahaan atau disebut Public Relations Krisis (crisis public relations). Istilah ini (crisis public relations) pertama kali digunakan Edward Bernays dalam menanggapi tuduhan kepada Standard Oil. (Biagi, 2010: 295). Salah satunya model strategi manajemen krisis dari Rhenald Kasali (adaptasi model anatomi krisis Steven Fink), yaitu Tahap Prodomal, Tahap Akut, Tahap Kronik, Tahap Resolusi atau (Penyembuhan)

\section{Daftar Pustaka}

Buku

Argenti, Paul. 2009. Corporate Communication. Penerjemah Putri Aila Idris. Komunikasi Korporat. Jakarta: Salemba Humanika, 2010.

Biagi, Shirley. 2010. Media/ Impact: An Introduction to Mass Media, 9th Ed. 
Penerjemah Mochammad Irfan dan Wulung Wira Mahendra. Media/ Impact: Pengantar Media Massa, Edisi 9. Jakarta: Salemba Humanika, 2010.

Cornelissen, Joep. Corporate Communications; Theory and Practice. London: Sage Pub., 2004.

Cutlip, M. Scott. et. al. 2006. Effective Public Relations, Ninth Edition. Penerjemah Tri Wibowo. B. S. . 2008. Effective Public Relations, Edisi Kesembilan. Jakarta: Kencana Prenada Media.

Gregory, Anne. 2008. "Public Relations and Management", hal.51-68. Alison Theaker (Ed.). 2008. The Public Relations Handbook. New York: Routledge.

Gregory, Anne. 2008. "Public Relations and Management", hal.51-68. Alison Theaker (Ed.). The Public Relations Handbook. New York: Routledge, 2008.

Jefkins, Frank dan Daniel Yadin. 1998.
Public Relations, Fifth Edition. Penerjemah Haris Munandar. 2003. Public Relations, Edisi Kelima. Jakarta: Erlangga.

Kasali, Rhenald. Manajemen Public Relations: Konsep dan Aplikasi di Indonesia. Jakarta: Grafiti, 1995.

\section{Non Buku}

Anonim. Crisis. Kamus Webster Online Dictionary. 2005. Http:// www. merriam-Webster.com. (diakses 4 September 2010).

Azmi, Ulul. 2009. Peranan Public Relations dalam Menangani Krisis Lingkungan (Study Kasus: Pencemaran Teluk Buyat). Materi Presentasi Kuliah pada Magister Ilmu Komunikasi-Sekolah Pascasarjana Universitas Sahid Jakarta. Http://www.scribd.com/ doc/27620791/Management-PublicRelation-Presentasi-Penanganan-KrisisKasus-Teluk-Buyat-Indonesia. (diakses 4 September 2010). 